\title{
Isolation of Cellulolytic Bacteria from the Peat Protected Forest Area in Sungai Buluh, East Tanjung Jabung Jambi
}

\author{
Fitratul Aini, ${ }^{*}$ Hasnaul Maritsa ${ }^{1}$, Hesti Riany ${ }^{2}$ \\ ${ }^{1}$ Department of Biology, Faculty of Science and Technology, Universitas Jambi \\ ${ }^{2}$ Department of Biology Education, Program Faculty of Tarbiyah Science and Teacher Sultan Thaha \\ Saifuddin Jambi
}

*email: fitratulaini47@gmail.com

Article Info

Key word:

Cellulose

Bacteria

Carboxy Methyl Cellulose

Peatland

Article history:

Received: 19/07/2021

Revised: 16/12/2021

Accepted: 27/12/2021

\begin{abstract}
One of the largest composition in peatlands is Cellulose. It can be degraded by cellulase enzymes. Sungai Buluh Peatland is one of the large and protected peatlands in Jambi Province. This land can be the main habitat for cellulolytic bacteria. Peatlands cellulolytic bacteria have great potential as biocontrol agents for plant pathogenic fungi. This study aimed to obtain cellulolytic soil bacteria from Sungai Buluh Tanjung Jabung Peat Protection Forest, in the East Tanjung Jabung, Jambi, which causes stem rot disease of oil palms. This research was carried out in several stages. Firstly, soil samples were collected from the Sungai Buluh Protected Forest, East Tanjung Jabung Jambi. Then the bacteria were selected on Carboxy Methyl Cellulose (CMC) selective media and the quantitative cellulolytic activities were measured based on clear zones that formed on CMC media. The results showed that 25 isolates of cellulolytic potential bacteria were obtained from the Sungai Buluh Peat Protected Forest area, 8 of them had cellulolytic activity range from 0.87 to 6.70 .
\end{abstract}

Copyright @ 2022 Author(s). All Right Reserved

\section{Introduction}

Indonesia is one of the countries with the largest peatland in tropical countries, which is approximately 15 million hectares. The land is located in several areas those are on the islands of Sumatra, Kalimantan and Papua (Ritung et al., 2011). Jambi Province has approximately 716.000 ha peatland, covering several regencies including 311.992,10 ha in East Tanjung Jabung Regency (Nurjannah et al, 2013). Unfortunately, peatland area in East Tanjung Jabung Regency has been widely used for oil palm plantations and housing. The land-used change has an impact on biogeochemical cycles in nature, the presence of bacteria and their abundance. The presence of bacteria in peatland has functions as decomposers and nutrients mineralization that are very beneficial for the environment (Macrae, 2013). In other hand, soil enzyme from microorganism has important role as ecosystem C cycling (Meng et al., 2020; Zi et al., 2018). Those enzymes act as an indicator of microbial function in response climate change especially in field condition (Zhou et al., 2013).

Cellulose is one of the largest composition in peatlands that can be 
degraded by cellulase enzymes. Cellulase enzymes can be produced by microbes that have cellulolytic abilities, including cellulolytic bacteria. Cellulolytic bacteria will convert cellulose into simpler monomers such as glucose. The ability of bacteria in producing cellulase enzymes can be utilized in various ways, it can be used as a biological agent or biocontrol in inhibiting the growth of plant pathogenic fungi.

Previous studies reported about the existence of some cellulolytic bacteria isolated from soil of Pontianak city (Rizmahardian \& Fadhilah, 2015) and one cellulolytic fungus isolated from peat soil of the Giam Biosphere Reserve in Siak Kecil, Bukit Batu Riau (Devitria R \& H, 2018). Moreover, three isolates of cellulolytic bacteria were collected from cowshed soil (Sembiring, 2019), and others four isolates of cellulolytic bacteria from waste soil also obtained (Hidayah \& Muhammad, 2017). Currently, the information about the potential of cellulolytic bacteria from the Buluh River Peat Protection Forest of East Tanjung Jabung Jambi is not available yet. Therefore, this study aims to isolate and collect the cellulolytic bacteria from the Buluh River Peat Protection Forest of East Tanjung Jabung Jambi area.

\section{Materials and Methods}

The materials were soil samples from peatland, Carboxy Methyl Cellulose (CMC) selective media, Potato Dextrose Agar (PDA), Nutrient Agar (NA), 70\% alcohol, distilled water, Spiritus, Congo red, and immersion oil.

\section{Soil Sampling}

Sampling was conducted by purposive sampling method, where the determination of the research location intentionally and considered representative of 3 different stations by 3 replications. Samples were collected at a depth of $20 \mathrm{~cm}$ below the soil surface using a modified PVC pipe. Then, soil samples were put into sample plastics and labelled based on the sampling station and continued by bacterial isolation that was conducted in the laboratory. The soil physical factors such as soil moisture, $\mathrm{pH}$ and temperature were measured for each sampling spot.

\section{Isolation and Selection of Cellulolytic Bacteria from Soil}

A total of 1 gram of soil sample put into a test tube containing $10 \mathrm{ml}$ of sterile distilled water. Then dilutions were carried out up to $10^{-6}$ (Cappuccino \& Sherman, 1992). In the last two dilutions, $0.1 \mathrm{~mL}$ was inoculated with three repetitions on CMC Agar media using the scatter dish method. Then, they were incubated for 48 hours at $32 \mathrm{C}$. The colonies that had been appeared were purified using quadrant streak plate.

\section{Cellulolytic bacterial activity test}

Cellulolytic bacterial activity test was carried out by growing bacterial isolates on $\mathrm{CMC}$ medium. Bacterial isolates that produced a clear zone indicated the ability of the isolates to degrade cellulose. The cellulolytic index $(\mathrm{CI})$ value was calculated using the ratio of the clear zone diameter value and the colony diameter value (Seprianto, 2017). The cellulose degradation ability of bacteria is classified based on cellulolytic index which are $\leq 1$ indicate low category and if moderate between 1 and 2 and high $\geq 2$ (Choi et al., 2005). And data were analysed based on the clear zone formed on CMC agar media.

\section{Results and Discussion Soil Sampling in the Sungai Buluh}

The research was conducted in the Sungai Buluh Peat Protected Forest. Soil samples were collected $10 \mathrm{~m}$ from the canal. The soil collected from three different depths those were $0 \mathrm{~cm}, 10 \mathrm{~cm}$, and $25 \mathrm{~cm}$. Other criteria for soil sampling were sunlight exposure those were open area (soil directly exposed to sunlight) and shady place (dense forest cover/lack of light). Monitoring was also carried out for first environmental conditions those were measurements of air temperature, soil $\mathrm{pH}$, air humidity, and light intensity (Table 1, Table 2 and Table 3). While samples were collected the soil surface was cleaned from the pile of litter using a shovel, then the 
sample was dug using a $100 \mathrm{~cm}$ in high of pipe. Next, soil was collected using a spatula which previously was sprayed by $70 \%$ alcohol. Then, the soil was placed into a sterile sample plastic and coded by the location, depth used, sunlight exposure. Finally, all of samples were placed into a cool box.

Table 1. Environmental Parameters in Soil Near Canal

\begin{tabular}{ccccc}
\hline $\begin{array}{c}\text { Soil } \\
\text { Depth } \\
(\mathbf{c m})\end{array}$ & $\begin{array}{c}\text { Temp } \\
\left({ }^{\circ} \mathbf{C}\right)\end{array}$ & $\mathbf{p H}$ & Lux & $\begin{array}{c}\text { Soil } \\
\text { Condition }\end{array}$ \\
\hline 0 & & & & $\begin{array}{c}\text { Dark brown, } \\
\text { lumpy and } \\
\text { moist } \\
\text { Black and } \\
\text { moist } \\
\text { Black and } \\
\text { watery }\end{array}$ \\
\hline
\end{tabular}

Isolation and Selection of Cellulolytic Bacteria Soil from Sungai Buluh

The isolates obtained were 25 isolates from 3 different stations and then characterized based on their morphology (Table 4).

Table 2. Environmental Parameters in Open Ground

\begin{tabular}{|c|c|c|c|c|}
\hline $\begin{array}{c}\text { Soil } \\
\text { Depth } \\
\text { (cm) }\end{array}$ & $\begin{array}{c}\text { Temp } \\
\left({ }^{\circ} \mathbf{C}\right)\end{array}$ & $\mathbf{p H}$ & Lux & $\begin{array}{c}\text { Soil } \\
\text { Condition }\end{array}$ \\
\hline 0 & & & & $\begin{array}{c}\text { Dark brown, } \\
\text { lumpy and } \\
\text { moist }\end{array}$ \\
\hline 10 & 31 & 5.9 & 301 & $\begin{array}{c}\text { Black and } \\
\text { moist }\end{array}$ \\
\hline 25 & & & & $\begin{array}{c}\text { Black and } \\
\text { watery }\end{array}$ \\
\hline
\end{tabular}

Table 3. Environmental Parameters in Shady Land

\begin{tabular}{ccccc}
\hline $\begin{array}{c}\text { Soil } \\
\text { Depth } \\
(\mathbf{c m})\end{array}$ & $\begin{array}{c}\text { Temp } \\
\left({ }^{\circ} \mathbf{C}\right)\end{array}$ & $\mathbf{p H}$ & $\mathbf{L u x}$ & Soil Condition \\
\hline 0 & & & & $\begin{array}{c}\text { Dark brown, } \\
\text { lumpy and } \\
\text { moist }\end{array}$ \\
10 & 29 & 5.9 & 290 & $\begin{array}{c}\text { Black and moist } \\
\text { Black and } \\
\text { watery }\end{array}$ \\
\hline
\end{tabular}

Table 4. Macroscopic Characteristics of Cellulolytic Bacteria from Three Locations in Sungai Buluh Peatland

\begin{tabular}{|c|c|c|c|c|c|c|c|}
\hline $\begin{array}{c}\text { Isolate } \\
\text { Code }\end{array}$ & Repetition & $\begin{array}{l}\text { Colony } \\
\text { Shape }\end{array}$ & Elevation & Margin & Size & Texture & Information \\
\hline \multirow{3}{*}{$\begin{array}{l}\text { TDK } \\
(0 \mathrm{~cm})\end{array}$} & $\mathrm{A}$ & Circular & Entire & Raised & Small & Smooth & Gray black colony \\
\hline & $\mathrm{B}$ & Circular & Entire & Raised & Small & Smooth & Milky white colony \\
\hline & $\mathrm{C}$ & Circular & Entire & Raised & Small & Smooth & Milky white colony \\
\hline \multirow{5}{*}{$\begin{array}{c}\text { TDK (10 } \\
\mathrm{cm})\end{array}$} & A & Filamentous & Rhizoid & Raised & Large & Smooth & Filamentous colony \\
\hline & B & Circular & Entire & Raised & Moderate & Smooth & $\begin{array}{l}\text { Small than moderate } \\
\text { colony, milky white }\end{array}$ \\
\hline & $\mathrm{C}$ & Circular & Entire & Flat & Puntiform & Smooth & Yellow colony \\
\hline & $\mathrm{D}$ & Circular & Entire & Raised & Small & Smooth & Yellowish white \\
\hline & $\mathrm{E}$ & Circular & Entire & Flat & Moderate & Smooth & Transparent colony \\
\hline \multirow{3}{*}{$\begin{array}{c}\text { TDK } \\
(25 \mathrm{~cm})\end{array}$} & A & Circular & Entire & Raised & Moderate & Smooth & Milky white colony \\
\hline & B & Circular & Undulate & Flat & Large & Smooth & $\begin{array}{c}\text { White and transparent } \\
\text { colony }\end{array}$ \\
\hline & $\mathrm{C}$ & Circular & Entire & Flat & Moderate & Smooth & Transparent colony \\
\hline \multirow{4}{*}{$\begin{array}{c}\text { TT } \\
(0 \mathrm{~cm})\end{array}$} & A & Irregular & Undulate & Raised & Large & Smooth & Milky white colony \\
\hline & $\mathrm{B}$ & Circular & Entire & Flat & Moderate & Smooth & Transparent colony \\
\hline & $\mathrm{C}$ & Circular & Entire & Raised & Moderate & Smooth & Milky white colony \\
\hline & $\mathrm{D}$ & Circular & Entire & Raised & Moderate & Smooth & Yellowish colony \\
\hline \multirow{3}{*}{$\begin{array}{c}\text { TT } \\
(10 \mathrm{~cm})\end{array}$} & A & Circular & Entire & Raised & Moderate & Smooth & Transparent colony \\
\hline & B & Circular & Entire & Raised & Moderate & Smooth & Milky white colony \\
\hline & $\mathrm{C}$ & Irregular & Undulate & Flat & Moderate & Smooth & $\begin{array}{l}\text { Milky white and } \\
\text { transparent colony }\end{array}$ \\
\hline \multirow{2}{*}{$\begin{array}{c}\text { TR } \\
(0 \mathrm{~cm})\end{array}$} & A & Irregular & Undulate & Flat & Moderate & Smooth & Milky white colony \\
\hline & B & Circular & Entire & Raised & Moderate & Smooth & $\begin{array}{l}\text { Milky white and } \\
\text { transparent colony }\end{array}$ \\
\hline
\end{tabular}


Table 4. Continue

\begin{tabular}{|c|c|c|c|c|c|c|c|}
\hline $\begin{array}{c}\text { Isolate } \\
\text { Code }\end{array}$ & Repetition & $\begin{array}{c}\text { Colony } \\
\text { Shape }\end{array}$ & Elevation & Margin & Size & Texture & Information \\
\hline \multirow{3}{*}{$\begin{array}{c}\text { TR } \\
(10 \mathrm{~cm})\end{array}$} & A & Circular & Entire & Raised & Moderate & Smooth & Milky white colony \\
\hline & B & Circular & Undulate & Flat & Moderate & Smooth & Transparent colony \\
\hline & $\mathrm{C}$ & Circular & Entire & Flat & Moderate & Smooth & $\begin{array}{l}\text { Transparent colony } \\
\text { under the light }\end{array}$ \\
\hline \multirow{2}{*}{$\begin{array}{c}\text { TR } \\
(25 \mathrm{~cm})\end{array}$} & A & Circular & Entire & Raised & Moderate & Smooth & Milky white colony \\
\hline & $\mathrm{B}$ & Circular & Entire & Flat & Moderate & Smooth & Transparent colony \\
\hline Notes: & & $\begin{array}{l}o \text { Land } N \epsilon \\
\text { pen Land }\end{array}$ & & 0,1 & $0,25 \mathrm{~cm}$ & : Depth & $\begin{array}{l}\text { ady } \\
\text { ampling point }\end{array}$ \\
\hline
\end{tabular}

\section{Cellulolytic Bacterial Activity from Soil of Sungai Buluh}

Cellulolytic bacterial activity was characterized by the appearance of a clear zone. The study showed that isolates at a location near the canal at a depth of $0 \mathrm{~cm}$ and $10 \mathrm{~cm}$ did not show a clear zone, but at a depth of $25 \mathrm{~cm}$ there were isolates that had a clear zone with a cellulolytic index of 3.59. This is caused by the remnants of leaves or litter are often carried away by water at the location near the canal at a depth of 0 and $10 \mathrm{~cm}$, especially when it rains. So that it was possibility as a cause of no cellulolytic bacteria are found, or created low cellulolytic activity in that location. The presence of cellulolytic bacteria is very closely related to the substrate of its natural habitat, the small amount of possibility of leaf remnants or litter in the location near the canal that is presumed to be cause of lower activity of the cellulolytic (Reanida et $a l ., 2012)$, that leaves that fall on the ground or leaf decay allows the cellulose content in the soil to be high, so it is possible to find cellulose-degrading bacteria in the soil. At a depth of $25 \mathrm{~cm}$, the remnants of fallen leaves are buried and this causes cellulolytic bacteria present to degrade cellulose into simple compounds. It leads cellulolytic bacteria to produce cellulase and then hydrolyses cellulose into simpler products, glucose (Hidayah \& Muhammad, 2017). The same study result was also reported by Fierer et al (2003), that around 35\% microbial biomass on total was found at depths $>25 \mathrm{~cm}$ and its density was the highest. And other study showed that density of cellulose bacteria in the peatland at depth above $3 \mathrm{~m}$ was smaller. It shown that cellulose bacterial density, especially in peatland influenced by aerobic and nutrition condition of the soil where their growth (Khotimah et al, 2021).

The bacteria from the open area locations at depths of 0,10 and $25 \mathrm{~cm}$ have created a clear zone in the media and showed cellulolytic index range of 0.87 to 6.70. Cellulolytic activity of the bacterial showed that the lower (deeper) the cellulolytic activity decreased. This is because the light in the bright locations allowed bacteria to degrade cellulose into simpler compounds. Sample from shady locations showed that the clear zone was found only at a depth of 0 and $10 \mathrm{~cm}$ with cellulolytic indexes of 1.67 and 2.07, while at a depth of $25 \mathrm{~cm}$ no clear zone was formed. This may be because of shady locations has higher humidity so cellulolytic bacteria compete with cellulolytic fungi, and fungi prefer locations with high humidity.

\section{Conclusion}

In this study, it was collected 25 isolates from eight different area. Then, Eight of Cellulolytic potential bacteria that were obtained from the Sungai Buluh Peat Protected Forest area had cellulolytic activity range from 0.87 to 6.70 . 


\section{Acknowledgments}

This research was funded by DIPA PNBP, Faculty of Science and Technology, University of Jambi.

\section{Reference}

Cappuccino, J. G., \& Sherman, N. (1992). Microbiology: A Laboratory Manual (3rd ed.). New York: Benjamin/Cumming Pub. Co.

Choi, Y. W., I. J. Hodgkiss, and K. D. Hyde. (2005) Enzyme Production by Endophytes of Brucea Javanica. J. Agri Tech, 1(5): 55-66 https://journals/Article/IJAT/10843226 .pdf

Devitria R, \& H, S. (2018). Isolasi dan Karakterisasi Fungi Selulolitik dari Tanah Gambut Cagar Biosfer Giam Siak Kecil-Bukit Batu Riau. Jurnal Akademika Kimia, 7(4), 200-205. doi.10.22487/j24775185.2018.v7.i4.11 945

Fierer, N., Schimela, J. P., \& Holden, P. A. (2003). Variations in microbial community composition through two soil depth profiles. Soil Biology \& Biochemistry, 35, 167-176. doi.10.1016/S0038-0717(02)00251-1

Hidayah, M., \& Muhammad, H. (2017). Isolasi dan Uji Aktivitas Enzim Selulase Pada Bakteri Selulolitik Asal Tanah Sampah. Agritrop, 15(2), 293308. doi.10.32528/agr.v15i2.1185

Khotimah, S., Suharjono, Ardyati, T., \& Nurani, Y. (2021). The potential of cellulose-degrading fungi at various peat maturities in Teluk Bakung Peat Area, Kubu Raya District, Indonesia. Biodiversitas, 22(4), 1981-1990. doi.10.13057/biodiv/d220446

Macrae. M dan J. P. A. R. C. W. (2013). Nutrient Mineralisation and Microbial Functional Diversity in A Restored Bog Approach Natural Conditions 10 years post restoration. Soil Biology \& Biochemistry, 64, 37-47. doi.10.1016/j.soilbio.2013.04.004

Meng, C., Tian, D., Zeng, H., Li, Z., Chen, H. Y. H., \& Niu, S. (2020). Global
Meta-analysis on the Responses of soil Extracellular Enzyme Activities to Warming. Science of The Total Environment, 705, 1-46. doi.10.1016/j.scitotenv.2019.135992

Nurjannah, N., Octavia, D., \& Kusumadewi, F. (2013). Identifikasi Lokasi Penanaman Kembali Ramin (Gonystylus bancanus Kurz) di Hutan Rawa Gambut Sumatera dan Kalimantan. Forda Press.

Reanida, Putri, P., Supriyanto, A., \& Salamun. (2012). Eksplorasi Bakteri Selulolitik dari Tanah Mangrove Wonorejo Surabaya. Universitas Airlangga, Surabaya. https://repository.unair.ac.id/25634/

Ritung, S., Wahyunto, Nugroho, K., Sukarman, Hikmatullah, Suparto, \& Tafakresnanto, C. (2011). Peta Lahan Gambut Indonesia, Skala 1:250.000 Kementerian Pertanian, Badan Penelitian dan Pengembangan Pertanian. Balai Besar Penelitian dan Pengembangan Sumberdaya Lahan Pertanian, Kementerian Pertanian. http://repository.pertanian.go.id/handle /123456789/5840

Rizmahardian, K. A., \& Fadhilah, R. (2015). Bakteri Selulolitik dari Tanah Gambut Dan Efek Fermentasinya Terhadap Komposisi Minyak Asiri Kulit Jeruk Pontianak. In Prosiding SEMIRATA 2015 Bidang MIPA BKS-PTN Barat, Universitas Tanjungpura Pontianak (pp. 190-196). https://jurnal.untan.ac.id/index.php/se mirata2015/article/view/14222

Sembiring, A. (2019). Isolasi dan Uji Aktivitas Bakteri Penghasil Selulase Asal Tanah Kandang Sapi. Jurnal Biology Science \& Education., 8(1), 21-28.

https://jurnal.iainambon.ac.id/843

Seprianto. (2017). Isolasi dan Penapisan Bakteri Selulolitik dari Berbagai Jenis Tanah sebagai Penghasil Enzim Selulase. Indonesian Journal of Biotechnology and Biodiversity, 1(1), 64-70. 
https://ejurnal.esaunggul.ac.id/index.p hp/bio/article/view/2102

Zhou, X., Chen, C., Wang, Y., Xu, Z., Han, H., Li, L., \& Wan, S. (2013). Warming and Increased Precipitation have Differential Effects on Soil Extracellular Enzyme Activities in a Temperate Grassland. Science of The Total Environment, 444, 552-558. doi.10.1016/j.scitotenv.2012.12.023
Zi, H. B., Hu, L., Wang, C. T., Wang, G. X., Wu, P. F., Lerdau, M., \& Ade, L. J. (2018). Responses of Soil Bacterial Community and Enzyme Activity to Experimental Warming of an Alpine Meadow. European Journal of Soil Science, 69(3), 429-438. doi.10.1111/ejss.12547 